\title{
Pengaruh Jenis Pelarut Terhadap Aktivitas Antioksidan Ekstrak Daun Kejompot (Crassocephalum crepidioides) Menggunakan Metode Maserasi
}

\section{Various Solvent Effect Towards Antioxidant Activity of Kejompot (Crassocephalum crepidioides) Extract With Maseration Method}

\author{
Maria Christinela Domithesa ${ }^{1}$, I Nengah Kencana Putra ${ }^{1^{*}}$, Anak Agung Istri Sri \\ Wiadnyani ${ }^{1}$
}

\author{
Program Studi Teknologi Pangan, Fakultas Teknologi Pertanian, Universitas Udayana \\ Kampus Bukit Jimbaran, Badung-Bali \\ *Penulis korespondensi: IN Kencana Putra, Email: nengahkencana@unud.ac.id
}

\begin{abstract}
This study aims to determine the effect of various solvent towards antioxidant activity of kejompot (crassocephalum crepioides) extract and to know the right solvent to obtained extract with the highest antioxidant activity. This study used a Completely Randomized Design Method with 4 treatment (water, methanol $70 \%$, ethanol $70 \%$, acetone $70 \%$,) using maseration method. The treatment was repeated four times to obtain 16 experimental units. If there was a significant effect on the observed parameters, then followed by Duncan multipple range test. The result showed that the treatment significantly effected $(\mathrm{P}<0.05)$ on each of parameters such as : yield, tanin total, flavonoid, vitamin $\mathrm{C}$, antioxidant activity. This study showed that methanol $70 \%$ as the best treatment that obtained yield, tannin, flavonoid, Vitamin $\mathrm{C}$ and antioxidant activity respectively $18.76 \%, 1.05 \mathrm{mg} \mathrm{TAE} / \mathrm{g}, 7.59 \mathrm{mg}$ QE/g, $8.68 \mathrm{mg}$ AAE/g, and 103.1 ppm antioxidant activity based on $\mathrm{IC}_{50}$.
\end{abstract}

Keywords : kejompot, extraction, solvent, antioxidant activity

\section{PENDAHULUAN}

Sayuran asli daerah atau sayuran introduksi yang telah berkembang lama dan dikenal masyarakat disuatu daerah tertentu serta banyak diusahakan dan dikonsumsi sejak zaman dahulu dikenal sebagai sayuran Indigenous (Putrasamedja, 2005). Salah satu jenis sayuran yang sering dimanfaatkan masyarakat Bali secara turun temurun sebagai pangan tradisional yaitu daun kejompot/kejengot/kepotpot atau dikenal juga sebagai daun sintrong (Crassocephalum crepidioides) oleh masyarakat Sunda. Kejompot merupakan tumbuhan semak belukar ataupun perdu yang tumbuh liar di wilayah tropis dan sub tropis. Tumbuhan ini dianggap sebagai gulma diantara tumbuhan lainya dan biasa dikonsumsi sebagai sayur oleh masyarakat Bali serta diyakini memiliki manfaat fungsional bagi tubuh.

Secara tradisional dipercaya bahwa tumbuhan ini dapat mengobati berbagai macam penyakit seperti gangguan pencernaan dan obat bisul (Kusdianti et al., 2008). Adjatin et al. (2013 ) melaporkan bahwa hasil uji kualitatif menunjukan kejompot memiliki kandungan senyawa fenolik seperti flavonoid, saponin, tanin. Selain itu dalam kejompot juga terdapat kandungan vitamin $\mathrm{C}$ (Adjatin et al., 2013). Berdasarkan penelitian- 
penelitian terdahulu yang dilakukan secara kualitatif, diketahui senyawa bioaktif dalam kejompot antara lain seperti : flavonoid, saponin dan tanin. Senyawa bioaktif dalam kejompot dapat diperoleh melalui proses ekstraksi. Maserasi merupakan salah satu jenis metode ekstraksi yang umum dan mudah untuk dilakukan karena dapat dilakukan dengan alat dan bahan-bahan yang sederhana.

Penelitian kejompot yang dilakukan oleh Lestari et al. (2015) dilaporkan bahwa proses ekstraksi menggunakan metode maserasi dengan pelarut etanol 96\%, pada penapisan fitokimia diketahui bahwa terdapat golongan senyawa flavonoid dan polifenol. Lebih lanjut dilaporkan kadar total fenol pada daun kejompot sebesar 1,8581 g GAE/100 g. Pasilala et al. (2016) melaporkan bahwa nilai $\mathrm{IC}_{50}$ ekstrak metanol daun kejompot yang diperoleh secara maserasi sebesar 369,0833 ppm.

Terdapat beberapa faktor yang mempengaruhi proses ekstraksi, salah satunya adalah jenis pelarut yang digunakan. Prinsip pemilihan pelarut dalam metode ekstraksi adalah menyesuaikan kepolaran pelarut dengan sifat komponen bioaktif yang hendak diekstrak. Sesuai dengan prinsip like dissolves like, yang menyatakan bahwa suatu pelarut akan cenderung melarutkan senyawa yang mempunyai tingkat kepolaran yang sama (Arifianti et al., 2014).

Berdasarkan penelitian yang telah dilakukan oleh Fathurrachman (2014) dalam pengujian aktivitas antioksidan ekstrak daun sirsak diperoleh hasil terbaik pada proses ekstraksi menggunakan pelarut etanol konsentrasi $70 \%$ menggunakan metode maserasi dengan nilai $\mathrm{IC}_{50}$ sebesar $18,030 \mathrm{ppm}$ sedangkan pada daun kersen, ekstrak yang diperoleh dari metanol 70\% menggunakan metode maserasi mampu menghasilkan aktivitas antioksidan yang tinggi yaitu sebesar 21,786 ppm (Kuntorini et al., 2013). Sementara itu Prayoga et al.(2019) melaporkan bahwa aseton 70\% juga mampu menghasilkan aktvitas antioksidan yang tinggi pada ekstrak daun pepe menggunakan metode maserasi sebesar 200,775 ppm. Jenis pelarut lainnya yang banyak digunakan dalam metode ekstraksi adalah pelarut air, karena selain harganya yang murah, keberadaanya yang mudah diperoleh dan tingkat kepolarannya yang tinggi. Berdasarkan pengujian yang dilakukan oleh Novita et al. (2016) terhadap aktivitas antioksidan dengan metode uji DPPH daun ubi kayu menggunakan pelarut air menunjukan hasil terbaik yaitu sebesar 22,92\%. Pada penelitian-penelitian tersebut menunjukan bahwa penggunaan pelarut dengan konsentrasi $70 \%$ mampu menghasilkan ekstrak dengan aktivitas antioksidan yang tinggi.

Sampai saat ini belum ditemukan penelitian yang melaporkan tentang jenis pelarut yang tepat untuk mengekstraksi senyawa bioaktif dalam kejompot. Oleh karena iru perlu dillakukan penelitian untuk mendapatkan jenis pelarut yang tepat untuk memperoleh 
ekstrak kejompot dengan aktivitas antioksidan terbaik.

\section{METODE PENELITIAN}

\section{Tempat dan Waktu Penelitian}

Penelitian ini dilaksanakan di Laboratorium Forensik Bareskrim Cabang Denpasar, Laboratorium Analisis Pangan dan Pengolahan Pangan Progran Studi Ilmu dan Teknologi Pangan Fakultas Teknologi Pertanian Universitas Udayana, Kampus Sudirman. Pelaksanaan penelitian ini dilakukan pada bulan Juni 2019 sampai dengan Agustus 2019.

\section{Bahan dan Alat}

Bahan-bahan yang digunakan dalam penelitian ini adalah daun kejompot (Crassocephalum crepidioides) yang diperoleh dari Dusun Kembang Sari, Desa Satra, Kintamani, Bangli. Bahan uji analisis yang diigunakan antara lain: Aquades, Etanol $70 \%$, Metanol 70\%, Aseton 70\%, 1,1diphenyl-2-picrylhydrazil (DPPH) (Sigma), $\mathrm{NaNO}_{2}(10 \%)$ (Merck), $\mathrm{AlCl}_{3}$ (10\%) (Merck), $\mathrm{NaOH}$ (15\%) (Merck), Kursetin (Sigma), Reagen Foolin Denis (Merck), $\mathrm{Na}_{2} \mathrm{CO}_{3}$ (Merck), Asam sulfat, Sodium phosphat, ammonium molybdate.

Alat yanng digunakan dalam pembuatan bubuk daun kejompot adalah: pisau, oven (Blue M), loyang, sendok, baskom, blender (Philips), pengayak berukuran 60 mesh (Retsch), tabung reaksi (pyrex), erlenmeyer (pyrex), corong buchner (pyrex), timbangan analitik (sartorius), rotary evaporator (IKA RV 10 basic), botol kaca, kertas saring whatman (no.1), spektrofotometer UV-VIS (Biochrom Libra), sentrifuse, vortex, pipet ukur, bola hisap, kuvet.

\section{Pelaksanaan Penelitian}

Proses ekstraksi dengan metode maserasi yang dilakukan pada penelitian ini merujuk pada penelitian yang telah dilakukan oleh Kemit et al. (2016) yang dimodifikasi. Proses analisis dibagi menjadi dua tahap yaitu persiapan sampel dan ekstraksi sampel.

\section{Persiapan Sampel}

Daun kejompot dibersihkan dengan air untuk menghilangkan kotoran dan ditiriskan. Selanjutnya daun kejompot lalu dioven dengan suhu $50^{\circ} \mathrm{C}$ selama \pm 8 jam. Setelah itu dihaluskan menggunakan blender, kemudian diayak menggunakan ayakan 60 mesh sehingga diperoleh bubuk kejompot.

\section{Ekstraksi Sampel}

Ekstraksi kejompot diawali dengan penimbangan bubuk kejompot masing-masing sebanyak $10 \mathrm{~g}$ lalu dilarutkan dengan variasi jenis pelarut (air, metanol $70 \%$, etanol $70 \%$ dan aseton $70 \%$ ) sebanyak $100 \mathrm{ml}$. Kemudian dimaserasi selama 30 jam Selanjutnya larutan disaring menggunakan kertas Whatman No. 1. Filtrat yang diperoleh dievaporasi menggunakan rotary vacuum evaporator dengan tekanan $24 \mathrm{kPa}$, temperatur $30^{\circ} \mathrm{C}$ dan putaran $100 \mathrm{rpm}$ Ekstrak yang didapat dikemas dengan botol gelap kemudian dianalisis rendemen, total tanin, flavonoid, vitamin $\mathrm{C}$ dan aktivitas antioksidan 


\section{Rancangan Percobaan}

Rancangan percobaan yang digunakan dalam penelitian ini adalah Rancangan Acak Lengkap (RAL) menggunakan perlakuan dengan 4 jenis pelarut yang berbeda yaitu $P_{1}=$ Air; $\mathrm{P}_{2}=$ Metanol 70\%; $\mathrm{P}_{3}=$ Etanol 70\%; $\mathrm{P} 4$ $=$ Aseton $70 \%$. Perlakuan masing-masing dilakukan sebanyak 4 kali ulangan sehinga diperoleh 16 unit perlakuan.

\section{Variabel yang diamati}

Parameter yang diamati dalam peneli elitian ini yaitu, total rendemen dengan metode AOAC (1990), kadar total tanin dengan metode Rajan et al.(2011), kadar total flavonoid dengan metode Singh et al., (2012), kadar total vitamin $\mathrm{C}$ dengan metode Vuong et al. (2014) dan aktivitas antioksidan dengan metode Burda dan Olezek (2001).

\section{HASIL DAN PEMBAHASAN}

\section{Total Rendemen Ekstrak Kejompot}

Hasil sidik ragam menunjukan bahwa jenis pelarut berpengaruh nyata $(p<0,05)$ terhadap total rendemen ekstrak kejompot. Total rendemen tertinggi diperoleh pada perlakuan menggunakan pelarut metanol $70 \%$ yaitu sebesar 18,76 sedangkan total rendemen terendah yaitu pada ekstrak kejompot dengan pelarut air yaitu $2,90 \%$

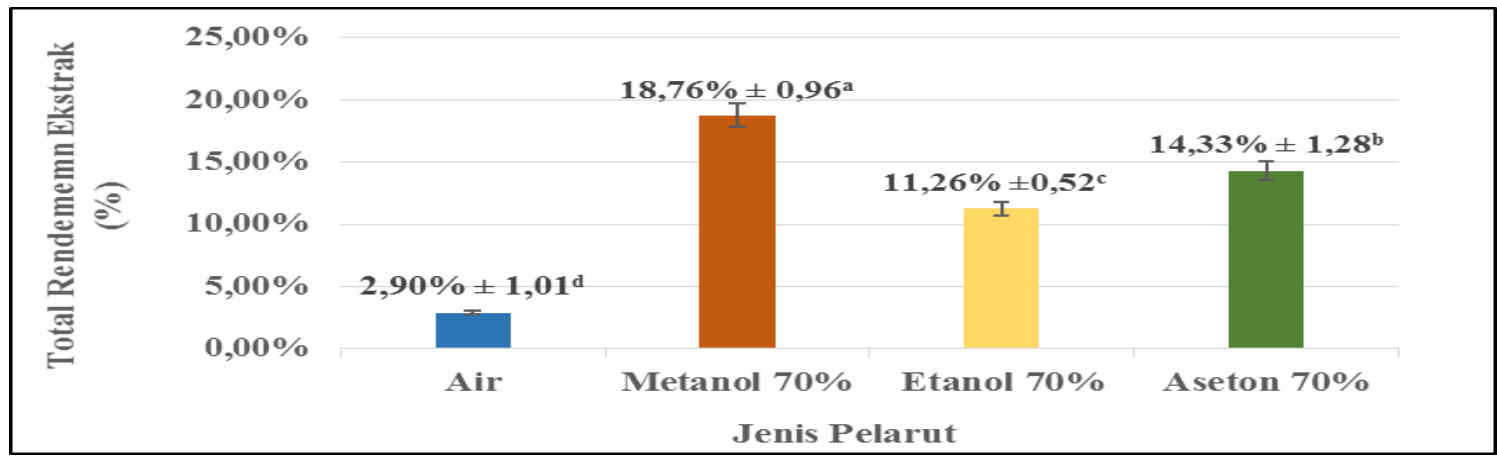

Keterangan: Notasi yang sama menunjukan perlakuan berbeda tidak nyata $(\mathrm{P}>0,05)$

\section{Gambar 1. Nilai rata-rata total rendemen kejompot}

Tingginya rendemen yang diperoleh pada ekstrak kejompot menggunakan pelarut metanol dibandingkan dengan pelarut lainnya diduga disebabkan oleh kesesuaian sifat kepolaran pelarut metanol dan bahan yang diekstrak.Tingginya rendemen yang terdapat pada pelarut metanol menunjukan bahwa pelarut tersebut mampu mengekstrak lebih banyak komponen bioaktif yang memiliki sifat kepolaran yang sesuai (Supiyanti et al., 2010). Penelitian lainya terhadap bunga lotus yang diekstrak menggunakan beberapa jenis pelarut berbeda juga menunjukan bahwa, ekstrak bunga lotus menggunakan pelarut metanol memberikan hasil rendemen terbaik dibandingkan pelarut lainnya, rendemen pada pelarut metanol adalah sebesar $0,708 \%$ (Romadanu et al., 2014). 


\section{Kadar Total Tanin Ekstrak Kejompot}

Hasil sidik ragam menunjukan bahwa jenis pelarut berpengaruh nyata $(p<0,05)$ terhadap kadar total tanin ekstrak kejompot. Data yang disajikan menunjukan bahwa perlakuan dengan pelarut etanol menghasilkan kadar total tanin tertinggi yaitu sebesar 1,13 mg TAE/g sedangkan, kadar total tanin terendah diperoleh pada perlakuan dengan perlakuan air yaitu sebesar $0,38 \mathrm{mg}$ TAE/g.

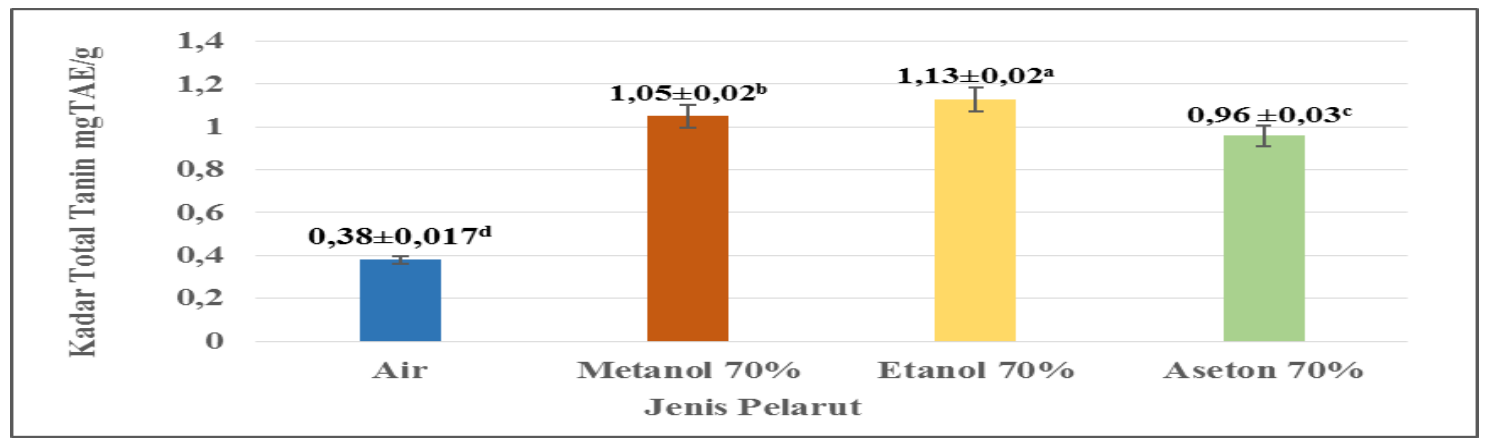

Keterangan : Notasi yang sama menunjukan perlakuan berbeda tidak nyata $(\mathrm{P}>0,05)$

Gambar 2. Nilai rata-rata total tanin kejompot

Berdasarkan data hasil penelitian yang diperoleh, pelarut etanol merupakan pelarut yang dapat mengekstrak tanin dalam daun kejompot paling efektif. Tingginya kadar tanin yang diperoleh menggunakan pelarut etanol disebabkan oleh tingkat kepolaran yang sama antara senyawa tanin yang hendak diekstrak dengan jenis pelarut yang digunakan (Lestari et al., 2014). Senyawa tanin juga diketahui memiliki kelarutan yang lebih tinggi dalam pelarut etanol yaitu sebesar 0,820 gram $/ \mathrm{ml}$ dibandingkan dengan pelarut lainnya yang sifatnya lebih polar seperti air yaitu, 0,656 gram $/ \mathrm{ml}$ (Ismail, 2010). Lestari et al. (2014) melaporkan bahwa ekstraksi daun alpukat menggunakan pelarut etanol menghasilkan kadar tanin tertinggi sebesar $22,07 \%$.

\section{Kadar Total Flavonoid Kejompot}

Hasil sidik ragam menunjukan bahwa jenis pelarut berpengaruh nyata $(\mathrm{p}<0,05)$ terhadap kadar total flavonoid ekstrak kejompot. Perlakuan dengan kadar total flavonoid tertinggi diperoleh pada perlakuan menggunakan pelarut aseton yaitu sebesar 9,00 mg QE/g sedangkan, kadar total flavonoid terendah diperoleh pada perlakuan dengan pelarut air yaitu sebesar 3,67 mg QE/g. 


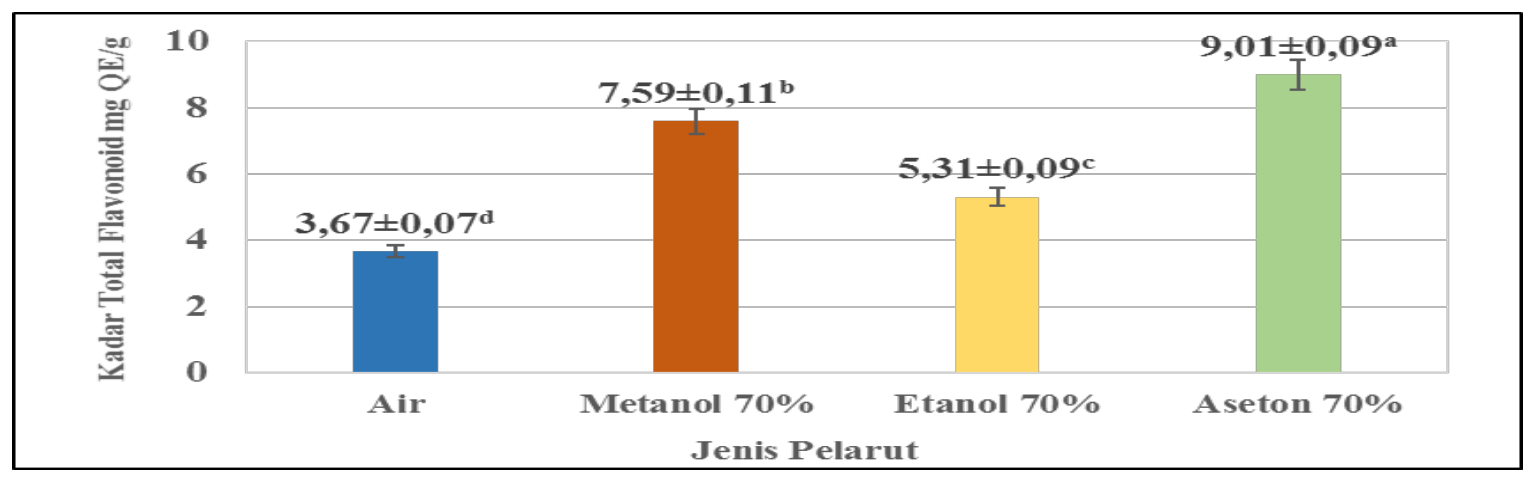

Keterangan : Notasi yang sama menunjukan perlakuan berbeda tidak nyata $(\mathrm{P}>0,05)$

Gambar 3. Nilai rata-rata total flavonoid kejompot

Hasil tersebut menunjukan bahwa aseton mampu mengekstrak senyawa flavonoid dalam daun kejompot secara efektif. Penelitian yang dilakukan oleh Moyo et al. (2012) pada ekstrak daun kelor secara maserasi menggunakan dua jenis pelarut berbeda yaitu air dan aseton menunjukan bahwa kadar total flavonoid terbaik diperoleh pada pelarut aseton yaitu sebesar 295,01 QE/g. Efektivitas suatu jenis pelarut dalam melarutkan suatu senyawa, dipengaruhi oleh tingkat kepolatan pelarut dan senyawa yang hendak diekstrak. Harborne (1987) menyebutkan bahwa golongan senyawa flavonoid terbagi dalam bebrapa jenis dan memiliki kepolaran yang berbeda - beda disetiap jenisnnya tergantung pada jumlah dan posisi gugus hidroksil menyebabkan senyawannya lebih mudah larut dalam pelarut polar. Sementara itu dalam bentuk aglikonnya, senyawa flavonoid cenderung kurang polar, sehinga lebih mudah larut dalam pelarut yang kurang polar (Hanani, 2017). Hal ini mengindikasikan bahwa senyawa flavonoid yang terdapat pada kejompot berbentuk aglikon sehingga cenderung larut dalam pelarut yang kurang polar seperti aseton.

\section{Kadar Total Vitamin C Ekstrak Kejompot}

Hasil sidik ragam menunjukan bahwa jenis pelarut berpengaruh nyata $(p<0,05)$ terhadap kadar total vitamin $\mathrm{C}$ ekstrak keompot. Perlakuan dengan total vitamin $\mathrm{C}$ tertinggi diperoleh pada perlakuan menggunakan pelarut aseton yaitu sebesar 9,92 mg AAE/g yang mana tidak berbeda nyata dengan kadar vitamin $\mathrm{C}$ pada ekstrak etanol kejompot yaitu sebesar 9,90 mg $\mathrm{AAE} / \mathrm{g}$ sedangkan, total vitamin $\mathrm{C}$ terendah diperoleh pada perlakuan air yaitu sebesar $1,17 \mathrm{mg} \mathrm{AAE} / \mathrm{g}$. 


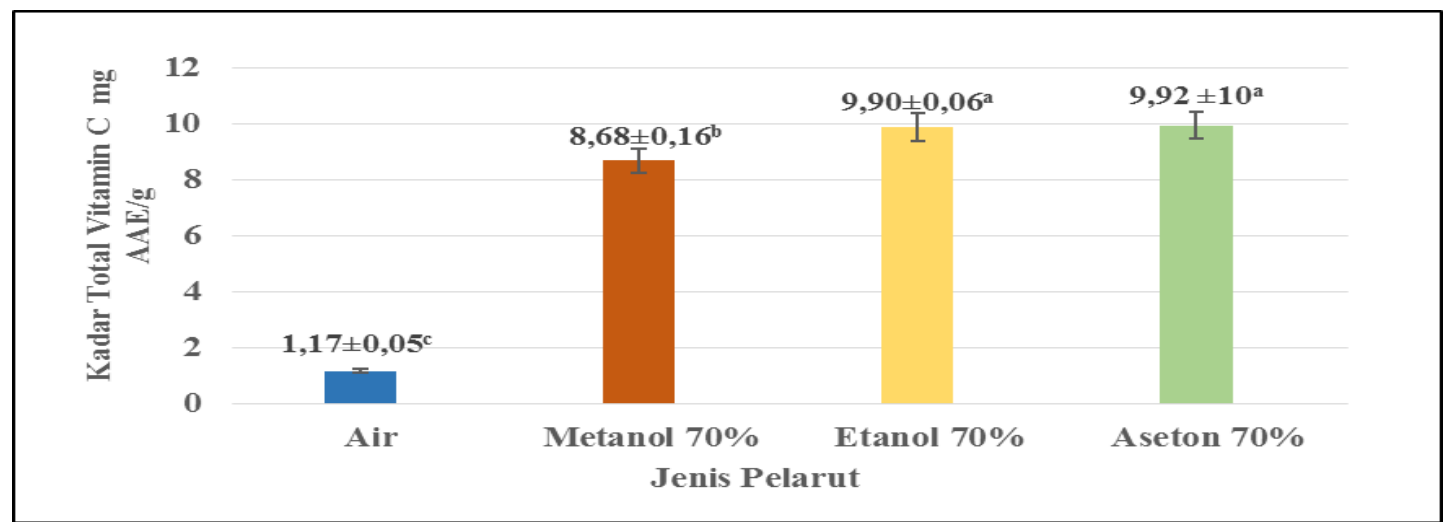

Keterangan: Notasi yang sama menunjukan perlakuan berbeda tidak nyata $(\mathrm{P}>0,05)$

\section{Gambar 4. Nilai rata-rata vitamin C kejompot}

Pelarut etanol dan aseton memiliki tingkat kepolaran yang lebih rendah bila dibandingkan dengan pelarut lainnya yang digunakan untuk mengekstrak kejompot seperti metanol dan air yang memiliki kepolaran lebih tinggi, hal ini mengindikasikan bahwa pelarut dengan kepolaran yang lebih rendah mampu mengekstrak vitamin $\mathrm{C}$ dengan lebih efektif. Hal ini didukung oleh penelitian yang dilakukan oleh Tahir et al, (2016) diketahui ekstrak vitamin $\mathrm{C}$ pada daun kelor menggunakan pelarut etanol menunjukan hasil yg cukup baik yaitu $7,96 \mathrm{mg} / \mathrm{g}$. Penelitian lainnya yang dilakukan pada ekstrak daun parsley dimana, sampel yang diekstrak menggunakan pelarut aseton $70 \%$ memiliki total vitamin $\mathrm{C}$ tertinggi yaitu sebesar 246,31 mg/100g dibandingkan perlakuan lainnya menggunakan pelarut metanol 80\% dan air (Kuzma et al., 2014).

\begin{abstract}
Aktivitas Antioksidan Ekstrak Kejompot
Hasil sidik ragam menunjukan bahwa jenis pelarut berpengaruh nyata $(p<0,05)$ terhadap aktivitas antioksidan ekstrak kejompot. Hasil yang diperoleh menunjukan bahwa aktivitas antioksidan tertinggi terdapat pada perlakuan pelarut metanol yaitu dengan aktivitas antioksidan sebesar $81,68 \%$ sedangkan, aktivitas antioksidan terendah ditunjukan pada ekstrak kejompot dengan perlakuan pelarut air yaitu sebesar $26,10 \%$.

Berdasarkan hasil analisis aktivitas antioksidan, pelarut metanol $70 \%$ memiliki persentase aktivitas antioksidan tertinggi sehingga perlakuan ini dipilih untuk diuji penentuan $\mathrm{IC}_{50}$. Grafik hubungan konsentrasi ekstrak dan aktivitas antioksidan ekstrak kejompot dapat dilihat pada Gambar 6 .
\end{abstract}




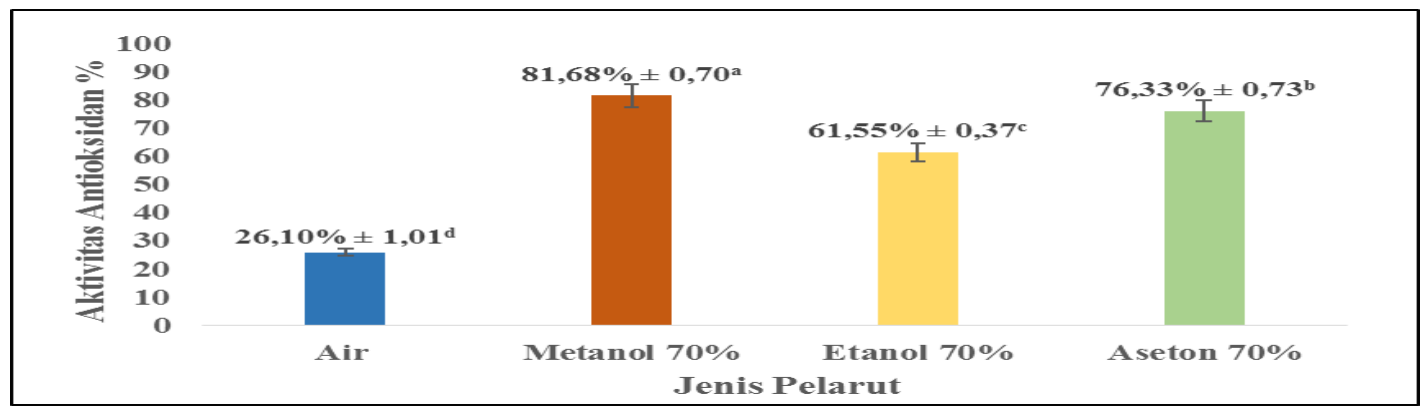

Keterangan: Notasi yang sama menunjukan perlakuan berbeda tidak nyata $(\mathrm{P}>0,05)$

Gambar 5. Nilai rata-rata aktivitas antioksidan kejompot

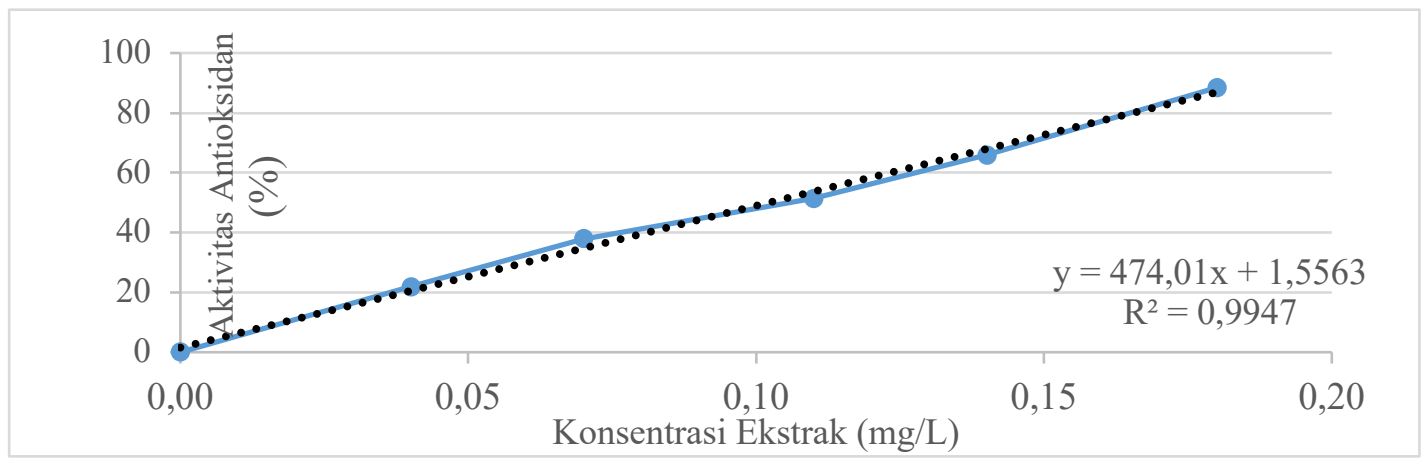

Gambar 6. Grafik hubungan konsentrasi Ekstrak dengan aktivitas antioksidan kejompot

Gambar 6. menunjukan bahwa peningkatan konsentrasi ekstrak berbanding lurus dengan presentase aktivitas antioksidan. Berdasarkan analisis regresi linier diperoleh persamaan yaitu $\mathrm{y}=474,01 \mathrm{x}+1,5563$. Nilai $\mathrm{x}$ merupakan nilai IC50 dan y bernilai 50 . Berdasarkan persamaan tersebut diperoleh nilai IC50 sebesar 103,01 ppm. Kejompot dapat digolongkan kedalam aktivitas antioksidan sedang. Nilai IC50 yang diperoleh menggambarkan besarnya konsentrasi suatu senyawa yang mampu menghambat radikal bebas (DPPH) sebanyak 50\%. Jika nilai IC50 semakin kecil maka kemampuan antioksidan semakin besar (Senevirathne et al., 2006). Nilai IC50 yang dimiliki oleh ekstrak kejompot lebih tinggi dibandingkan nilai IC50 ekstrak metanol daun ubi kayu yaitu sebesar 16,060 ppm namun, IC50 ekstrak kejompot lebih rendah dari ekstrak metanol daun kangkung air yaitu sebesar 290,09 ppm.

Tingginya kemampuan meredam radikal bebas dalam ekstrak metanol kejompot menunjukan bahwa komponen bioaktif dalam kejompot mampu terekstrak dengan baik didalam metanol. Pelarut metanol merupakan pelarut yang sifatnya paling polar setelah pelarut air diantara pelarut lainnya yang digunakan dalam 
penelitian ini. Setiawan et al,(2017) juga mengatakan bahwa pelarut metanol merupakan jenis pelarut yang mampu melarutkan hampir semua zat baik yang sifatnya polar, semi polar ataupun non polar. Novita et al. (2016) melaporkan bahwa ekstrak metanol daun ubi kayu menghasilkan aktivitas antioksidan tertinggi dibandingkan dengan daun ubi kayu yang diekstrak dengan pelarut air. Hal ini mengindikasikan bahwa komponen bioaktif yang terkandung dalam daun kejompot merupakan golongan monoglikosida yang menyebabkan kelarutan senyawa bioaktif dalam kejompot menjadi rendah dan lebih larut dalam metanol (Tsumbu et al., 2011).

\section{KESIMPULAN DAN SARAN}

\section{Kesimpulan}

Jenis pelarut berpengaruh terhadap kadar total rendemen, tanin, flavonoid, aktivitas antioksidan dan vitamin ekstrak kejompot. Pelarut terbaik yang digunakan untuk mengekstrak kejompot adalah pelarut metanol $70 \%$, yang memiliki rendemen sebesar $18,76 \%$, total tanin $1,05 \mathrm{mg} \mathrm{TAE} / \mathrm{g}$, total flavonoid 7,59 mg QE/g, Vitamin C 8,68 mg AAE/g, dan aktivitas antioksidan 103,1 ppm.

\section{Saran}

Pelarut metanol merupakan jenis pelarut terbaik yang dapat digunakan dalam ekstraksi antioksidan kejompot. Kejompot dengan potensinya sebagai antioksidan dapat dikembangkan menjadi pangan fungsional dan nutraseutical contohnya : dalam bentuk sumpelem sehingga pemanfaatannya menjadi lebih luas.

\section{DAFTAR PUSTAKA}

Adjatin $^{\text {a }, ~ A ., ~ A . D a n s i ., ~ E . B a d o u s s i ., ~ Y . L . L o k o ., ~}$ M.Dansi., P.Azokpota., F.Gbaguidi., H.Ahissou., A.Akoegninou., K.Akpagana., dan A.Sanni. 2013. Phytochemical screening and toxicity studies of Crassocephalum rubens (Juss. Ex Jacq.) S. Moore and Crasscephalum crepidioides (Benth.) S. Moore Consumed as vegetable in Benin. International Journal of Current Microbiology and Applied Sciences. 2(8) : 1-13.

Adjatin $^{b}$ A., A. Dansi., E. Badoussi., A. F. Sanoussi., M. Dansi., P. Azokpota., H. Ahissou., A. Akouegninou., K. Akpagana., dan A. Sanni. 2013. Proximate, mineral and Vitamin C composition of vegetable Gbolo [Crassocephalum rubens (Juss. ex Jacq.) S. Moore and C. crepidioides (Benth.) S. Moore] in Benin. International Journal Biology Chemistry Science. 7(1) : 319-331.

AOAC. 1999. Official Methods of Analysis of The Association of Official Analytical Chemical. AOAC Inc, Washington.

Arifianti, L., R.D. Oktarina, dan I. Kusumawati. 2014. Pengaruh jenis pelarut pengektraksi terhadap kadar sinensetin dalam ekstrak daun Orthosiphon Stamineus Benth. EJournal Planta Husada. 2(1): 1-4

Burda, S dan W. Ozelek. 2001. Antioxidant and Antiradical Activitiies of Flavonoids. International Journal Agriculture : Food Chemistry.

Fathurrachman, D.A. 2014. Pengaruh Konsentrasi Pelarut Terhadap Aktivitas Antioksidan Ekstrak Etanol Daun Sirsak (Annona Muricata Lin) Dengan Metode Perendaman Radikal Bebas (DPPH). Skripsi S1. Tidak dipublikasikan. Fakultas Kedokteran dan Ilmu Kesehatan. UIN Syarifhidayatullah. Jakarta

Hanani, E. 2017. Analisis Fitokimia. Penerbit Buku Kedokteran EGC, Jakarta.

Harborne, J. B.1987. Metode Fitokimia: Penuntun Cara Modern Menganalisis Tumbuhan. Terjemahan oleh Padmawinata K, Soedira I. 1996. Bandung: Penerbit Institut Teknologi Bandung. 
Ismail.2010. Flowsheet Pra Rancangan Pembuatan Tanin dari Biji Pinang Kapasitas Produksi 27.775 ton/tahun. Laporan Tugas Akhir Departemen Teknik Kimia Universitas Sumatra Utara.

Kemit, N., I.W.R. Widarta., K.A. Nocianitri. 2016. Pengaruh jenis pelarut dan waktu maserasi terhadap kandungan senyawa flavonoid dan aktivitas antioksidan ekstrak daun alpukat (Persea Americana Mill.). Jurnal Ilmu dan Teknologi Pangan. 5(2) : 130-141.

Kuntorini, F.M., S.Fitriani dan M.D.Astuti.2013. Struktur Anatomi Uji Aktivitas Antioksidan Ekstrak Metanol Daun Kersen (Muntingin calabura). Prosiding Semitrata FMIPA Universitas Lampung. 291-296.

Kusdianti, T.S. Nilawati, L. Sheba. 2008. Tumbuhan Obat Di Legok Jero Situ Lembang. Makalah Seminar Hasil. Tidak dipublikasikan. Fakultas Pendidikan Matematika dan Ilmu Pengetahuan Alam, Universitas Pendidikan Indonesia, Bandung.

Kuzma, P., B.Druzynska., M.Obzienski. 2014. Optimazation of extraction condition of some polyphenolic compounds fromparsley leaves (Petroselinum Crispum).Acta Scientarium Polonorum. 13(2) : 145-154.

Lestari,P., S.Wijana.,W.I. Putri. 2014. Ekstraksi Tanin Dari Daun Alpukat (Persea Americana Mill.) sebagai Pewarna Alami (Kajian Proporsi Pelarut dan Waktu Ekstraksi). Skripsi S1. Tidak dipublikasikan. Departemen Teknologi Industri Pertanian Fakultas Teknologi Pertanian Universitas Brawijaya.

Lestari,T., A, Nurmala., dan M, Nurmalasari. 2015. Penetapan Kadar Polifenol Dan Aktivitas Antibakteri Ekstrak Etanol Daun Sintrong (Crassocephalum Crepidiodes (Benth.) S. Moore). Jurnal Kesehatan Bakti Tunas Husada. 13 (1): 107-112.

Moyo,B., S.Oyedemi., P.J. Masika., V. Muchenje. 2012. Polyphenolic content and antioxidant properties od Moringa oleifera leaf extract and enzymatic activity of liver from goats suplemented with Moringa oleifera leaf sunflower or seed cake. Meat Science. 91 (2012) : 441-447.

Novita, M., M.I. Sulaiman., dan S.Yura. 2016. Pengaruh jenis pelarut terhadap aktivitas antioksidan dan kandungan fenol beberapa jenis bayam dan sayuran lain. Jurnal Ilmiah Pertanian Unsiyah. 1(1) : 935-940.

Pasilala, B.F., Daniel., C. Saleh. 2016. Uji toksisitas (brine shrimp lethality test) dan aktivitas antioksidan dari daun sintrong (crassocephalum crepidioides) dengan metode 2,2-diphenyl-1-picrylhidrazil (DPPH). Jurnal Kimia Mulawarman. 14(1): $13-18$

Prayoga, D.G.E., K.A.Nocianitri, dan N.N.Puspawati.2019.Identifikasi Senyawa Fitokimia dan Aktivitas Antioksidan Ekstrak Kasar Daun Pepe (Gymnema reticulatum Br) pada Berbagai Jenis Pelarut. Jurnal Ilmu dan Teknologi Pangan. 8(2):111-121.

Putrasamedja, S.2005. Elsplorasi dan Koleksi Sayuran Indigenous di Kabupaten Karawang, Purwakarta dan Subang. Buletin Plasma Nutfah. 11(1) : 16-20.

Pasilala, B.F., Daniel., C. Saleh. 2016. Uji toksisitas (brine shrimp lethality test) dan aktivitas antioksidan dari daun sintrong (crassocephalum crepidioides) dengan metode 2,2-diphenyl-1-picrylhidrazil (DPPH). Jurnal Kimia Mulawarman. 14(1): $13-18$

Prayoga, D.G.E., K.A.Nocianitri, dan N.N.Puspawati.2019.Identifikasi Senyawa Fitokimia dan Aktivitas Antioksidan Ekstrak Kasar Daun Pepe (Gymnema reticulatum Br) pada Berbagai Jenis Pelarut. Jurnal Ilmu dan Teknologi Pangan. 8(2):111-121

Putrasamedja, S.2005. Elsplorasi dan Koleksi Sayuran Indigenous di Kabupaten Karawang, Purwakarta dan Subang. Buletin Plasma Nutfah. 11(1) : 16-20.

Rajan, S., S. Mahalakshmi., VM. Deepa., K.Sathya.,S.Shajitha.,T.Thirunalasundari.

2011. Antioxidant potentials of punica granatum fruit rind extraxts. International Journal Pharmacy Sci. 3 : 82- 88.

Romadanu, S.H. Rachmawati., S.D. Lestari. 2014. Pengujiian Aktivitas Antioksidan Ekstrak Bunga Lotus (Nelumbo nucifera). Fistech Journal, 3(1) : 1-7. 